\title{
FAKTOR-FAKTOR YANG MEMPENGARUHI KEPUTUSAN NON MUSLIM MENJADI ANGGOTA PADA KSPPS FASTABIQ KHOIRU UMMAH PATI
}

\author{
Kharis Fadlullah Hana \\ Institut Agama Islam Negeri Kudus, Kudus \\ $\bowtie$ kharishana181@gmail.com
}

\begin{abstract}
The purpose of this study was to find out what factors influence the decision of non-Muslims to become members of the Savings and Loans Cooperative (KSPPS) Fastabiq Khoiru Ummah Pati. Cooperatives are joint business entities that move to improve the welfare of their members based on sharia principles. The sharia cooperative is a new instrument in financial institutions in Indonesia, but its development has experienced a very significant increase. From the data of the Indonesian Central Bureau of Statistics, it was stated that there were 498 business entities in the form of sharia cooperatives spread across various provinces throughout Indonesia. This is influenced by the high interest of the community to become members of both Muslim and non-Muslim circles. The situation is interesting to note that cooperatives based on Islamic sharia principles are also in demand among non-Muslims. Innovative services, promotions and products that are in accordance with the daily needs of the community are the things that most influence their decisions.
\end{abstract}

Keywords : Products, Promotions, Services and Non Muslim Decision

\section{LATAR BELAKANG}

Pasar keuangan syariah merupakan elemen baru di Indonesia, namun dalam 10 tahun terakhir menunjukkan perkembangan yang cukup pesat. Hal itu dapat dilihat dari tumbuhnya perbankan syariah, asuransi syariah, dan reksadana syariah. Seperti lembaga keuangan konvensional lainnya, lembaga keuangan syari'ah merupakan lembaga keuangan yang mempunyai fungsi diantaranya menghimpun dana dari masyarakat dalam bentuk simpanan dan menyalurkan kemasyarakat dalam bentuk pinjaman atau modal kerja. Namun yang membedakan antara dua lembaga tersebut adalah jika pada lembaga keuangan konvensional sebagian besar operasionalnya ditentukan oleh kemampuannya dalam menghimpun dana masyarakat melalui pelayanan dan pemberian bunga yang menarik. Maka tidak dengan lembaga keuangan syari'ah, lembaga ini memiliki produk dan jasa yang berkarakteristik diantaranya peniadaan atas pembebanan bunga yang berkesinambungan, membatasi kegiatan spekulasi yang tidak produktif dan pembiayaan ditujukan kepada usaha-usaha yang halal sesuai prinsip syari'ah. 
Salah satu dari sekian banyak lembaga keuangan yang mendasarkan seluruh aktivitasnya pada prinsip syari'ah bebas bunga adalah Koperasi Simpan Pinjam dan Pembiayaan Syariah (KSPPS). (Ridwan, 2004) KSPPS merupakan bentuk lembaga dan bisnis dibawah otonomi Kementerian Koperasi. Peran umum KSPPS yang dilakukan adalah melakukan pembinaan dan pendanaan yang berdasarkan sistem syari'ah. Peran ini menegaskan arti penting prinsip-prinsip syari'ah dalam kehidupan ekonomi masyarakat. Sebagai lembaga keuangan syari'ah yang bersentuhan langsung dengan kehidupan masyarakat kecil yang serba cukup-ilmu pengetahuan ataupun materi maka KSPPS mempunyai tugas penting dalam mengemban misi keislaman.

Begitu juga KSPPS Fastabiq Khoiru Ummah yang didirikan pada tahun 1999. Sekarang, KSPPS itu telah menjadi sebuah Lembaga Keuangan yang diperhitungkan. Betapa tidak, dari modal awal Rp 2 juta, sekarang Fastabiq telah mengelola dana sebesar Rp 280 miliar yang berdiri atas dasar kekuatan umat. Baitul mall Wat Tamwill (BMT) yang bernama Fastabiq atau sekarang dikenal dengan KSPPS Fastabiq Khoiru Ummah yang berlokasi di JL. Raya Pati-Tayu Km.3 Tambaharjo Pati dengan No.telp 0295-383999, fax 0295-383936 Email: kjksbmtfastabiq@telkom.nets.

Sejarah berdirinya KSPPS Fastabiq Khoiru Ummah dilatar belakangi atas keprihatinan para pemuda muhammadiyah akan tingkah laku umat islam yang mengelola harta bendanya berdasarkan prinsip konvensional. Pada suatu saat Pemuda Muhammadiyah bertemu untuk menghadiri Muktamar Pemuda Muhammadiyah ke XI pada tanggal 1 s.d 4 juli 1998. Membangun ide melalui diskusi perjalanan darat (dalam bus) selama 4 hari dari Semarang menuju Riau. Muhammad Ridwan, Muhammad Sapuan, Abdul Hadi, Ahmad Mubasyirin, Abdul Wachid, merupakan utusan dari Pimpinan Daerah Pemuda Muhammadiyah Pati.

Atas dasar kenyataan diatas maka diadakan kajian intensif solusi keprihatinan kondisi tersebut, dan lahirlah gagasan ide untuk mendirikan lembaga keuangan syari'ah sebagai media kaderisasi dan kemandirian pendanaan. Gagasan ide tersebut ditindak lanjuti oleh Pimpinan Daerah Pemuda Muhammadiyah Pati, dengan mengadakan rapat pada hari sabtu tanggal 25 juli 1998 di SMA Muhammadiyah Pati, yang dihadiri oleh 33 orang dan memutuskan membentuk badan usaha otonom yang dinamakan Baitul Mall Wat Tamwil Fastabiq yang selanjutnya disingkat BMT Fastabiq.

Dengan dasar payung hukum Koperasi Serba Usaha (KSU) Fatabiq yang pendiriannya disahkan oleh menteri koperasi pengusaha kecil dan menengah melalui SK Nomor: 011/BH/KDK.11.9/x/1998 tanggal 31 Oktober 1998, secara resmi mulai beroperasi tangggal 18 Nopember 1998 yang merupakan tonggak awal berdirinya BMT Fastabiq.

Berdasarkan Rapat Anggota Khusus pada tanggal 9 Oktober 2004 diputuskan perubahan AD/ART menjadi KJKS (Koperasi Jasa Keuangan Syariah) BMT Fastabiq. Berdasarkan keputusan Bupati a.nMenteri Negara koperasi dan Usaha kecil dan Menengah nomor: 518/758/V/2006 tentang pengesahan Akta perubahan Anggaran Dasar Koperasi jasa Keuangan Syariah BMT Fastabiq, untuk selanjutnya disebut: KJKS BMT Fastabiq, dengan badan hukum nomor: 011 a/BH/PAD/V/2006.

Pada hari sabtu tanggal 24 januari 2009, bertempat di Ruang Fastabiq Convention Centre Jalan raya pati tayu km 4 Pati telah dilaksanakan Rapat anggota Khusus (RAK) Perubahan Anggaran Dasar Koperasi jasa Keuangan Syari'ah (KJKS) BMT Fastabiq pati tentang perubahan pengembangan wilayah tingkat Jawa Tengah.

Hasil Rapat khusus di atas telah mendapat Pengesahan perubahan AD dari Dinas Koperasi dan UMKM Prop. Jateng No.07/PAD/KDK.11/IV/2009 tanggal 7 April 2009. Terakhir pada tahun 2017 KJKS BMT Fastabiq berganti nama menjadi KSPPS Fastabiq 
Khoiru Ummah berdasarkan keputusan dari Kementerian Koperasi._KSPPS Fastabiq dengan kantor pusat di tambaharjo Pati sudah memiliki 24 cabang dan beberapa lembaga dibawah manajemen fastabiq diantaranya adalah Rs. Fastabiq sehat, Fastabiq resik dan Fastabiq Institute.

Kredibilitas Fastabiq dibuktikan dengan semakin bertambahnya anggota dari tahun ke tahun yang mengalami peningkatan yang signifikan. Hal ini dipengaruhi dari beberapa faktor anggota memutuskan untuk menjadi anggota. Minat mereka adalah berdasarkan keunggulan dari Fastabiq sendiri yaitu pelayanan dengan jemput bola, promosi yang menarik dengan memberikan souvenir dan berbagai keuntungan lainnya. Anggota yang menabung dan pembiayaan sendiri berasal dari berbagai kalangan, baik dari muslim maupun non muslim. Mereka yang beragama non muslim banyak yang menyimpan dananya dan melakukan pembiayaan murobohah untuk pembelian kendaraan dan berbagai macam barang untuk kebutuhan usahanya. Hal ini bisa di lihat di cabang mayong jepara, cluwak, keling dan berbagai cabang lainnya yang disekitarnya terdapat keberagaman.

\section{TEORI DAN METODE}

\subsection{Produk, Promosi dan Pelayanan}

Produk ( product) adalah segala sesuatu yang dapat ditawarkan ke pasar untuk mendapatkan perhatian, dibeli, digunakan, atau dikonsumsi yang dapat memuaskan keinginan atau kebutuhan. Secara konseptual produk adalah pemahaman subyektif dari produsen atas sesuatu yang bisa ditawarkan sebagai usaha untuk mencapai tujuan organisasi melalui pemenuhan kebutuhan dan kegiatan konsumen, sesuai dengan kompetensi dan kapasitas organisasi serta daya beli pasar. Selain itu produk dapat pula didefinisikan sebagai persepsi konsumen yang dijabarkan oleh produsen melalui hasil produksinya. Produk dipandang penting oleh konsumen dan dijadikan dasar pengambilan keputusan pembelian. (Philip Kotler, 2001)

Menurut Kotler \& Armstrong beberapa atribut yang menyertai dan melengkapi produk (karakteristik atribut produk) adalah: Merek (brand) adalah nama, istilah, tanda, simbol, atau rancangan, atau kombinasi dari semua ini yang dimaksudkan untuk mengidentifikasi produk atau jasa dari satu atau kelompok penjual dan membedakannya dari produk pesaing. Pemberian merek merupakan masalah pokok dalam strategi produk. Pemberian merek itu mahal dan memakan waktu, serta dapat membuat produk itu berhasil atau gagal. Nama merek yang baik dapat menambah keberhasilan yang besar pada produk. Pengemasan (packing)

adalah kegiatan merancang dan membuat wadah atau pembungkus suatu produk. Kualitas Produk (Product Quality) adalah kemampuan suatu produk untuk melaksanakan fungsinya meliputi, daya tahan keandalan, ketepatan kemudahan operasi dan perbaikan, serta atribut bernilai lainnya. Untuk meningkatkan kualitas produk perusahaan dapat menerapkan program "Total Quality Manajemen (TQM)". Selain mengurangi kerusakan produk, tujuan pokok kualitas total adalah untuk meningkatkan nilai pelanggan. (Philip Kotler, 2001)

Promosi merupakan kegiatan yang ditujukan untuk mempengaruhi konsumen agar mereka dapat menjadi kenal akan produk yang ditawarkan oleh perusahaan kepada mereka dan kemudian menjadi senang lalu membeli produk tersebut. (Indriyo, 1997) Promosi merupakan sarana yang paling ampuh untuk menarik dan mempertahankan anggota. Adapun alat-alat yang dapat dipergunakan untuk mempromosikan suatu produk, dapat dipilih beberapa cara yaitu: iklan, promosi 
penjualan, publikasi dan personal selling. Promosi penjualan didefinisikan sebagai kumpulan alat-alat intensif yang beragam, sebagian besar berjangka pendek, dirancang untuk mendorong pembelian suatu produk atau jasa tertentu secara lebih cepat dan atau lebih besar oleh konsumen atau pedagang. (Kasmir, 2005)

Promosi penjualan menawarkan intensif untuk membeli. Promosi penjualan mencakup alat untuk promosi konsumen (sampel, kupon, tawaran pengembalian uang, potongan harga, premi, hadiah, hadiah langganan, percobaan gratis, garansi, promosi berhubungan, promosi silang, pajangan dan demonstrasi ditoko tempat pembelian); promosi perdagangan (potongan harga, tunjangan iklan dan pajangan, barang gratis); promosi bisnis dan wiraniaga (pameran dan konvensi perdagangan, kontes untuk wiraniaga dan iklan khusus). Kiat promosi penjualan digunakan oleh sebagian besar organisasi, termasuk perusahaan manufaktur, distributor, pengecer, asosiasi perdagangan, dan organisasi nirlaba. Sebagai contoh yang terakhir, gereja biasanya mensponsori permainan bingo, pesta teater, makan malam kesaksian dan bazar. Alat promosi penjualan berbeda-beda dalam hal spesifiknya. Contoh gratis mendorong konsumen untuk mencoba, sementara jasa konsultan manajemen gratis bertujuan untuk mempererat hubungan jangka panjang dengan seorang pengecer. (Philip Kotler, 2001)

Pelayanan merupakan kunci keberhasilan dalam berbagai usaha atau kegiatan yang bersifat jasa. Peranannya akan lebih besar dan bersifat menentukan manakala dalam kegaiatan-kegiatan jasa di masyarakat itu terdapat kompetisi dalam usaha merebut pasaran atau langganan. Suatu perusahaan seperti perbankan untuk menarik perhatian nasabah harus memiliki layanan yang baik agar anggota merasa puas. Telah kita ketahui bahwa dalam memberikan pelayanan seorang pegawai koperasi simpan pinjam dan pembiayaan syariah juga diperlukan etiket, sehingga kedua belah pihak baik tamu maupun pegawai dapat saling menghargai.

Seorang marketer harus pandai dalam melakukan promosi. Dalam menjalankan tugas hal ini kaitannya dengan promosi, marketer muslim harus memiliki jiwa Syari'ah Marketer. Dalam Islam ada empat karakteristik marketing syari'ah (Syari'ah Marketing) yang dapat dijadikan panduan bagi para marketer, diantaranya sebagai berikut: Teitis (Rabbaniyah): jiwa seorang syari'ah marketer meyakini bahwa hukumhukum syari'at yang teistis atau bersifat keTuhanan ini adalah hukum yang paling adil, paling sempurna, paling selaras dengan segala bentuk kebaikan. Seorang syari'ah marketer akan segera mematuhi hukum-hukum syari'ah dalam segala aktivitasnya begitu juga dengan Marketing mix-nya, dalam mendesain produk, menetapkan harga, dalam melakukan promosi, senantiasa dijiwai oleh nilai-nilai religius. (Hermawan, 2006)

Etis (Akhlaqiyyah): sifat etis sebenarnya merupakan turunan dari sifat teistis (Rabbaniyah), selain karena teistis (Rabbaniyyah), syari'ah marketer harus mengedepankan akhlak (moral, etika) dalam seluruh aspek kegiatannya.

Realistis (al-waqi'iyyah): Syari'ah Marketing bukanlah konsep yang eksklusif, fanatis, anti-modernitas, dan kaku. Syari'ah Marketing, adalah konsep pemasaran yang fleksibel, sebagaimana keluasan dan keluwesan Syari'ah Islamiyah yang melandasinya.

Humanistis (insaniyyah): bahwa syari'ah diciptakan untuk manusia agar derajatnya terangkat, sifat kemanusiaannya terjaga dan terpelihara, serta sifat-sifat kehewanannya dapat terkekang dengan panduan syari'ah.

Selanjutnya dalam menetapkan anggota yang loyal maka dibangun dengan suatu pelayanan yang baik. Pelayanan sendiri yaitu suatu kegiatan yang menolong menyediakan segala apa yang diperlukan orang lain atau konsumen dengan 
penampilan produk yang sebaik-baiknya sehingga diperoleh kepuasan pelanggan dan usaha pembelian yang berulang-ulang. (Sedyana, 1995)

\subsection{Metode Penelitian}

Jenis penelitian yang penulis gunakan yaitu penelitian yang datanya diperoleh langsung dari tempat kejadian berlangsung, dari objek yang diteliti dengan cara riset atau penelitian lapangan (field research). (Saifuddin, 2004) Sedangkan pendekatan penelitian dengan menggunakan pendekatan kuantitatif menekankan analisisnya pada data-data numerikal (angka) yang diolah dengan metode statistik.

Dalam penelitian ini penulis menggunakan penelitian kuantitatif, karena data yang diperoleh nantinya berupa angka. Dari angka yang diperoleh akan dianalisis lebih lanjut dalam analisis data. Penelitian ini terdiri atas dua variabel, yaitu Produk, Promosi dan Pelayanan sebagai variabel bebas (independent) dan Keputusan non muslim menjadi nasabah sebagai variabel terikat (dependent) dengan menggunakan data sebagai bahan ukuran penelitian.

Data merupakan bahan yang diolah dengan baik melalui proses analisis dalam memperoleh informasi. Pengumpulan data dapat menggunakan sumber primer dan sumber sekunder. Data primer adalah data yang didapat dari sumber pertama baik dari individu atau perseorangan, maka proses pengumpulan datanya perlu dilakukan dengan memperhatikan siapa sumber utama yang akan dijadikan objek penelitian. (Muhammad, 2008) Adapun sumber data primer dari penelitian ini penulis peroleh dari 50 anggota Non Muslim KSPPS Fastabiq Khoiru Ummah dari 24 cabang yang ada di Karesidenan Pati.

Data sekunder adalah sumber yang tidak langsung memberikan data kepada pengumpul data. Adapun sumber data sekunder dari penelitian ini penulis peroleh dari KSPPS Fastabiq Khoiru Ummah dan berbagai informasi yang telah dipublikasikan baik jurnal ilmiah, penelitian terdahulu, majalah dan literatur yang berhubungan dengan penelitian ini. Data sekunder dimaksudkan agar dapat memberikan ilustrasi umum dan dapat mendukung hasil penelitian.

\section{HASIL DAN PEMBAHASAN}

\subsection{Hasil Analisis Data}

\subsubsection{Karakteristik Responden}

Data penelitian dikumpulkan dengan melakukan penyebaran angket sebanyak 50 kuesioner yang diberikan kepada anggota KSPPS Fastabiq Khoiru Ummah seluruh cabang. Dari 50 kuesioner diperoleh gambaran tentang profil responden.

Tabel 1. Profil Responden

\begin{tabular}{l|c|c}
\hline \multicolumn{1}{c|}{ Keterangan } & Jumlah & Persentase \\
\hline Gender & 16 & $32 \%$ \\
- Laki-laki & 34 & $68 \%$ \\
- Perempuan & & \\
\hline Usia & 9 & $18 \%$ \\
- 17 s/d 29 tahun & 28 & $56 \%$ \\
- 30 s/d 40 tahun & 13 & $26 \%$ \\
- Lebih dari 40 tahun & & \\
\hline Pendidikan Terakhir & 0 & $0 \%$ \\
- Tidak sekolah & &
\end{tabular}




\begin{tabular}{l|c|c} 
- SD & 2 & $4 \%$ \\
- SMP & 10 & $20 \%$ \\
- SMA & 26 & $52 \%$ \\
- Sarjana & 12 & $24 \%$ \\
\hline Penghasilan & 8 & $16 \%$ \\
- < j juta & 12 & $24 \%$ \\
- 1 juta s/d 2 juta & 15 & $30 \%$ \\
- 2 juta s/d 3 juta & 6 & $12 \%$ \\
- 3 juta s/d 4 juta & 9 & $18 \%$ \\
- >4 juta & 7 & $14 \%$ \\
\hline Pekerjaan & 15 & $30 \%$ \\
- PNS & 24 & $48 \%$ \\
- Karyawan & 4 & $8 \%$ \\
- Wiraswasta & &
\end{tabular}

\subsection{Uji Validitas dan Reliabilitas}

\subsubsection{Uji Validitas}

Uji validitas digunakan untuk mengukur sah atau tidaknya suatu koesioner. Untuk mengetahui valid dan tidaknya suatu pertanyaan tersebut maka dapat diketahui dengan cara membandingkan $r$ hitung (nilai corrected item-total correlation) dengan $r$ tabel dk n-2 signifikansi 5\%. Dari hasil pengolahan SPSS diperoleh hasil sebagai berikut:

Tabel 2. Hasil Uji Validitas

\begin{tabular}{c|c|c|c}
\hline $\begin{array}{c}\text { Item } \\
\text { Pertanyaan }\end{array}$ & r hitung & r table & Keterangan \\
\hline PRD 1 & 0.631 & 0.284 & Valid \\
\hline PRD 2 & 0.705 & 0.284 & Valid \\
\hline PRD 3 & 0.634 & 0.284 & Valid \\
\hline PRD 4 & 0.552 & 0.284 & Valid \\
\hline PRD 5 & 0.588 & 0.284 & Valid \\
\hline PRM 1 & 0.585 & 0.284 & Valid \\
\hline PRM 2 & 0.542 & 0.284 & Valid \\
\hline PRM 3 & 0.642 & 0.284 & Valid \\
\hline PRM 4 & 0.788 & 0.284 & Valid \\
\hline PRM 5 & 0.780 & 0.284 & Valid \\
\hline PLY 1 & 0.642 & 0.284 & Valid \\
\hline PLY 2 & 0.710 & 0.284 & Valid \\
\hline PLY 3 & 0.679 & 0.284 & Valid \\
\hline PLY 4 & 0.680 & 0.284 & Valid \\
\hline PLY 5 & 0.488 & 0.284 & Valid \\
\hline KNM 5 & 0.649 & 0.284 & Valid
\end{tabular}

Berdasarkan Tabel 4.3 diketahui bahwa masing-masing item yang menyusun masing-masing kuesioner memiliki $r$ hitung lebih dari $r$ table ( $r$ hitung $>0,284$ ), yang berarti masing-masing item dari variabel adalah valid. Dengan demikian syarat validitas dari alat ukur terpenuhi. 


\subsubsection{Uji Reliabilitas}

Uji reliabilitas adalah alat untuk mengukur suatu kuesioner yang merupakan indikator dari variabel atau konstruk. Berdasarkan hasil pengolahan SPSS diperoleh hasil sebagai berikut:

Tabel 3. Hasil Uji Reliabilitas

\begin{tabular}{l|c|c|c|c}
\hline \multicolumn{1}{c|}{ Kuesioner } & $\begin{array}{c}\text { Jumlah } \\
\text { Item }\end{array}$ & $\begin{array}{c}\text { Alpha } \\
\text { Cronbach }\end{array}$ & R hit & Keterangan \\
\hline Produk (X1) & 5 & 0.819 & 0.6 & Reliabel \\
\hline Promosi (X2) & 5 & 0.852 & 0.6 & Reliabel \\
\hline Pelayanan (X3) & 5 & 0.836 & 0.6 & Reliabel \\
\hline $\begin{array}{l}\text { Keputusan Anggota Non } \\
\text { Muslim (Y) }\end{array}$ & 5 & 0.817 & 0.6 & Reliabel
\end{tabular}

Berdasarkan Tabel 4.3 diketahui bahwa semua variabel memiliki nilai cronbach alpha yang lebih tinggi dari 0,6, maka dikatakan reliabel. Dengan demikian syarat reliabilitas alat ukur terpenuhi.

\subsection{Statistik Deskriptif}

Statistik deskriptif merupakan tanggapan responden atas item-item pertanyaan dalam kuesioner. Adapun hasilnya dapat dilihat pada tabel berikut ini

Tabel 4. Descriptive Statistics

\begin{tabular}{l|r|r|r|r|r}
\hline & N & Minimum & Maximum & Mean & Std. Deviation \\
\hline Produk & 50 & 12 & 24 & 19.58 & 3.182 \\
\hline Promosi & 50 & 12 & 24 & 19.22 & 3.272 \\
\hline Pelayanan & 50 & 10 & 25 & 19.88 & 3.041 \\
\hline $\begin{array}{l}\text { Keputusan Anggota } \\
\text { Non Muslim }\end{array}$ & 50 & 14 & 25 & 20.38 & 2.571 \\
\hline
\end{tabular}

Sumber; data primer yang diolah

Berdasarkan tabel di atas diketahui Variabel produk memiliki kisaran antara 12 sampai dengan 24 yang dilakukan pengamatan terhadap 50 responden. Rata-rata nilai produk dari 50 responden adalah 19.58 dengan standar deviasi sebesar 3.182. Nilai rata-rata yang lebih tinggi dari standar deviasi mengindikasikan bahwa jawaban kuesioner tentang produk antara satu responden dengan responden lainnya adalah tidak berbeda.

Promosi memiliki nilai maksimum 12 dan minimum 24 yang diperoleh dari 50 responden. Rata-rata nilai promosi dari 50 responden adalah 19.22 dengan standar deviasi sebesar 3.272. Standar deviasi yang lebih rendah dari rata-ratanya menunjukkan jawaban tentang promosi antar responden adalah tidak jauh berbeda.

Variabel pelayanan dilakukan pengamatan terhadap 50 responden memiliki nilai maximum 25 dan nilai minimum adalah 10. Rata-rata dari pelayanan dari 50 responden adalah 19.88 dengan standar deviasi sebesar 3.041. Nilai rata-rata yang lebih tinggi dari nilai standar deviasi dapat disimpulkan bahwa jawaban tentang pelayanan dari responden satu dengan lainnya tidak jauh berbeda.

Keputusan non muslim menjadi anggota memiliki nilai maksimum 14 dan minimum 25 yang diperoleh dari 50 responden. Rata-rata nilai keputusan nasabah non muslim dari 50 responden adalah 20.38 dengan standar deviasi sebesar 2.571. Standar 
deviasi yang lebih rendah dari rata-ratanya menunjukkan jawaban tentang keputusan non muslim menjadi anggota antar responden adalah tidak jauh berbeda.

\subsection{Uji Asumsi Klasik}

Setelah diadakan uji reliabilitas dan validitas, untuk memeriksa agar tidak terjadi penyimpangan kuesioner dan hasilnya telah memenuhi validitas dan reliabilitas. Secara umum sebenarnya sudah terpenuhi dengan uji reliabilitas dan validitas, namun penelitian ini ingin mencermati lebih teliti sehingga masih dilakukan prosedur uji penyimpangan asumsi klasik dengan uji multikolonieritas, uji autokorelasi, uji heteroskedastisitas, dan uji normalitas

\subsubsection{Uji Multikolinearitas}

Uji multikolinearitas bertujuan untuk menguji apakah regresi diketemukan adanya korelasi antar variabel bebas (independen). Model regresi yang baik tentu tidak terjadi korelasi di antara variabel bebas.

Tabel 5. Hasil Uji Multikolinearitas

\begin{tabular}{l|c|c}
\hline \multirow{2}{*}{ Variabel } & \multicolumn{2}{|c}{ Collinearity Statistics } \\
\cline { 2 - 3 } & Tolerance & VIF \\
\hline Produk (X1) & 0.614 & 1.629 \\
\hline Promosi (X2) & 0.689 & 1.452 \\
\hline Pelayanan (X3) & 0.772 & 1.296
\end{tabular}

Dari tabel di atas menunjukkan bahwa hasil perhitungan nilai tolerance kurang dari $10 \%$ yang berarti tidak ada korelasi antar variabel bebas yang nilainya lebih dari 95\%. Hasil perhitungan nilai varian inflation factor (VIF) juga menunjukkan hal yang sama tidak ada satu variabel bebas yang memiliki nilai VIF lebih dari 10. Jadi dapat disimpulkan tidak ada multikolinearitas antar variabel bebas dalam model regresi.

\subsubsection{Uji Heteroskedastisitas}

Uji ini bertujuan untuk menguji apakah dalam model regresi terjadi ketidaksamaan variance dari residual satu pengamatan ke pengamatan yang lain. Jika variance dari residual ke pengamatan yang lain tetap maka disebut heteroskedastisitas. Salah satu cara untuk mengetahui ada atau tidaknya heteroskedastisitas yaitu dengan melihat grafik plots antara nilai prediksi variabel dependen.

\section{Gambar 1.1}

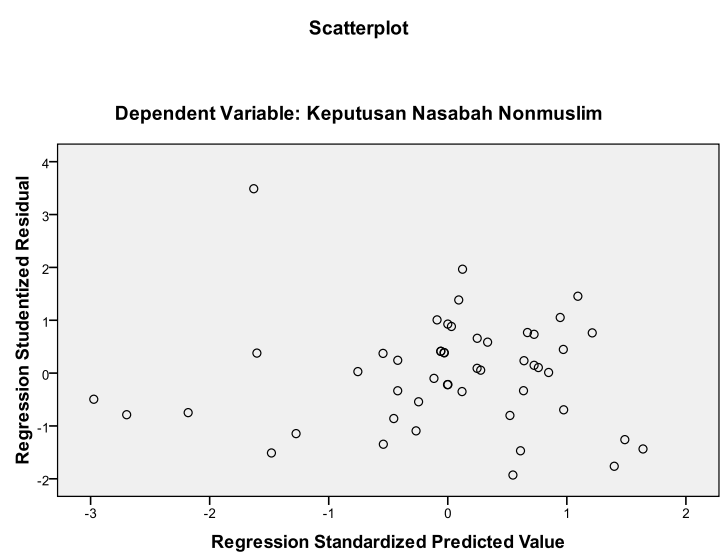

Berdasarkan grafik di atas, kita dapat melihat bahwa tidak ada pola yang jelas, serta titik-titik yang menyebar di atas dan di bawah angka 0 pada sumbu Y, maka Ho "diterima" artinya tidak terjadi heteroskedastisitas. 


\subsubsection{Uji Normalitas}

Uji normalitas bertujuan untuk menguji apakah dalam model regresi, nilai residual mempunyai distribusi normal atau tidak. Uji normalitas dapat dilakukan dengan melihat normal probability plot. Dari hasil SPSS diperoleh hasil sebagai berikut:

\section{Gambar 1.2}

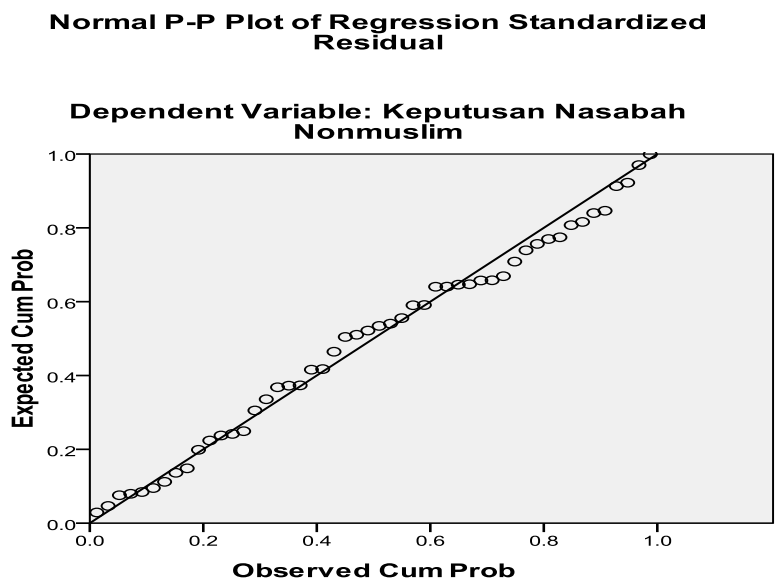

Berdasarkan grafik di atas diketahui data tersebut menyebar di sekitar garis diagonal dan mengikuti arah garis grafiknya sehingga dapat dikatakan bahwa nilai residual adalah berdistribusi normal.

\subsection{Analisis Regresi}

Penelitian ini menggunakan analisis regresi, dimana variabel dependen (keputusan non muslim menjadi anggota) diregres terhadap produk, promosi dan pelayanan.

\subsubsection{Koefisien Determinasi}

Koefisien determinasi pada intinya mengukur seberapa jauh kemampuan model dalam menerangkan variasi variabel dependen. Berdasarkan pengolahan SPSS di peroleh hasil sebagai berikut:

\begin{tabular}{l|l|r|r|r}
\multicolumn{5}{c}{ Tabel 6. Model Summary } \\
\hline Model & R & R Square & $\begin{array}{c}\text { Adjusted R } \\
\text { Square }\end{array}$ & $\begin{array}{c}\text { Std. Error of } \\
\text { the Estimate }\end{array}$ \\
\hline 1 & $.735^{\mathrm{a}}$ & .540 & .510 & 1.799
\end{tabular}

Tampilan output SPSS model summary menunjukkan hubungan yang dinotasikan dengan $\mathrm{R}$ antara produk, promosi dan pelayanan terhadap keputusan anggota non muslim adalah sebesar 0.735 dengan kategori kuat. Besarnya koefisien determinasi yang dinotasikan nilai adjusted $\mathrm{R}^{2}$ yaitu sebesar 0.510 yang berarti variabilitas keputusan anggota non muslim dapat dijelaskan oleh variabel produk, promosi dan pelayanan sekitar 51\% dan sisanya 49\% dijelaskan oleh variabel lain di luar model. Nilai SEE sebesar 1.799 mengindikasikan bahwa semakin kecil nilai SEE, makin tepat model dalam memprediksi variabel terikat.

\subsubsection{Uji Signifikansi Simultan (Uji F)}

Uji statistik F pada dasarnya menunjukkan apakah semua variabel bebas yang dimasukkan dalam model mempunyai pengaruh secara bersama-sama terhadap variabel terikat. Berdasarkan pengolahan SPSS diperoleh hasil sebagai berikut: 
Tabel 7. Uji F (Uji Simultan)

\begin{tabular}{|c|c|c|c|c|c|c|}
\hline & Model & $\begin{array}{l}\text { Sum of } \\
\text { Squares }\end{array}$ & Df & $\begin{array}{l}\text { Mean } \\
\text { Square }\end{array}$ & $\mathrm{F}$ & Sig. \\
\hline \multirow[t]{3}{*}{1} & Regression & 174.830 & 3 & 58.277 & 17.997 & $.000^{\mathrm{a}}$ \\
\hline & Residual & 148.950 & 46 & 3.238 & & \\
\hline & Total & 323.780 & 49 & & & \\
\hline
\end{tabular}

Sumber: hasil pengolahan SPSS

Hasil anova menunjukkan bahwa nilai $\mathrm{F}$ hitung sebesar 17.997 dengan tingkat signifikansi 0.000 jauh di bawah 0.05 . Hal ini berarti bahwa model adalah fit atau dapat dikatakan variabel independen (produk, promosi dan pelayanan) secara bersamasama atau simultan mempengaruhi keputusan anggota non muslim.

\subsubsection{Uji Signifikan Parameter Individual (Uji t Statistic)}

Uji statistik t pada dasarnya menunjukkan seberapa jauh pengaruh satu variabel independen secara individual dalam menerangkan variasi variabel dependen. Berdasarkan pengolahan SPSS diperoleh hasil sebagai berikut:

Tabel 8. Coefficients ${ }^{a}$

\begin{tabular}{|c|c|c|c|c|c|c|}
\hline \multirow{2}{*}{\multicolumn{2}{|c|}{ Model }} & \multicolumn{2}{|c|}{$\begin{array}{l}\text { Unstandardized } \\
\text { Coefficients }\end{array}$} & \multirow{2}{*}{$\begin{array}{c}\begin{array}{c}\text { Standardized } \\
\text { Coefficients }\end{array} \\
\text { Beta } \\
\end{array}$} & \multirow[b]{2}{*}{$\mathrm{T}$} & \multirow[b]{2}{*}{ Sig. } \\
\hline & & B & Std. Error & & & \\
\hline 1 & (Constant) & 5.832 & 2.029 & & 2.875 & .006 \\
\hline & Produk & 228 & .103 & .282 & 2.212 & .032 \\
\hline & Promosi & .286 & .095 & .364 & 3.020 & .004 \\
\hline & Pelayanan & .231 & .096 & .273 & 2.398 & .021 \\
\hline
\end{tabular}

Hasil tampilan di atas maka ditulis persamaan sebagai berikut:

$\mathrm{Y}=5.832+0.231 \mathrm{X} 1+0.228 \mathrm{X} 2+0.286 \mathrm{X} 3+\mathrm{e}$

Persamaan di atas dapat dijelaskan sebagai berikut:

1) Konstanta sebesar 5.832 menyatakan bahwa jika variabel independen dianggap konstan maka rata-rata keputusan anggota non muslim menjadi anggota adalah sebesar 5.832

2) Koefisien regresi produk adalah $0.228(22,8)$ berarti bahwa jika produk naik 10 kali akan meningkatkan keputusan anggota non muslim sebesar 2.28 kali.

3) Koefisien regresi promosi adalah $0.286(28,6)$ berarti bahwa jika promosi naik 10 kali akan meningkatkan keputusan anggota non muslim sebesar 2,86 kali.

4) Koefisien regresi dari pelayanan adalah $0.231(23,1)$ berarti bahwa jika pelayanan naik 10 kali akan meningkatkan keputusan anggota non muslim sebesar 2.31 kali

\subsection{Pembahasan}

Pengujian ini dilakukan untuk menjawab menjawab hipotesis yang telah diajukan pada bab sebelumnya. Pengujian ini terdiri atas:

a) Pengaruh Produk terhadap Keputusan anggota Non Muslim

Berdasarkan tabel 4.10 menunjukkan bahwa variabel produk memberikan nilai koefisien sebesar 0.228 dengan standar error 0.103 Dari kedua nilai ini 
menghasilkan t hitung sebesar 2.212 dengan probabilitas (signifikansi) sebesar 0.032 yang di bawah 0.05 . Sehingga dapat disimpulkan bahwa variabel produk berpengaruh positif signifikan terhadap keputusan anggota non muslim.

b) Pengaruh Promosi terhadap keputusan Anggota Non Muslim

Berdasarkan tabel 4.10 menunjukkan bahwa variabel promosi memberikan nilai koefisien sebesar 0.286 dengan standar error 0.095. Dari kedua nilai ini menghasilkan t hitung sebesar 3.020 dengan probabilitas (signifikansi) sebesar 0.004 yang di bawah 0.05. Sehingga dapat disimpulkan bahwa variabel promosi berpengaruh positif signifikan terhadap keputusan anggota non muslim.

c) Pengaruh Pelayanan terhadap Keputusan Anggotah Non Muslim

Berdasarkan tabel 4.10 menunjukkan bahwa variabel pelayanan memberikan nilai koefisien sebesar 0.231 dengan standar error 0.096. Dari kedua nilai ini menghasilkan t hitung sebesar 2.398 dengan probabilitas (signifikansi) sebesar 0.021 yang di bawah 0.05 . Sehingga dapat disimpulkan bahwa variabel pelayanan berpengaruh positif terhadap keputusan anggota non muslim.

d) Pengaruh Produk, Promosi dan Pelayanan terhadap Keputusan Anggota Non Muslim

Berdasarkan tabel 4.9 (Anova) menunjukkan bahwa ketiga variabel bebas memberikan nilai Fhitung sebesar sebesar 17.997 dengan probabilitas (signifikansi) 0.000 . Melihat nilai probabilitas (signifikansi) sebesar 0.000 yang jauh di bawah 0.05. Sehingga dapat disimpulkan bahwa secara bersama-sama variabel pelayanan, produk dan promosi berpengaruh signifikan terhadap keputusan anggota non muslim.

\section{PENUTUP}

Berdasarkan hasil penelitian, maka dapat disimpulkan sebagai berikut:

1) Produk berpengaruh signifikan terhadap keputusan anggota non muslim. Hal ini dilihat dari nilai koefisien regresi sebesar 0.228 dengan signifikansi 0.032 yang jauh di bawah 0.05 , sehingga hipotesis yang menyatakan ada pengaruh yang signifikan produk terhadap keputusan anggota non muslim pada KSPPS Fastabiq Khoiru Ummah Pati diterima.

2) Promosi berpengaruh signifikan terhadap keputusan anggota non muslim. Hal ini dilihat dari nilai koefisien regresi sebesar 0.286 dengan signifikansi 0.004 yang jauh di bawah 0.05 , sehingga hipotesis yang menyatakan ada pengaruh yang signifikan promosi terhadap keputusan anggota non muslim pada KSPPS Fastabiq Khoiru Ummah Pati diterima.

3) Pelayanan berpengaruh signifikan terhadap keputusan anggota non muslim. Hal ini dilihat dari nilai koefisien regresi sebesar 0.231 dengan signifikansi 0.021 yang jauh di bawah 0.05 , sehingga hipotesis yang menyatakan ada pengaruh yang signifikan pelayanan terhadap keputusan anggota non muslim pada KSPPS Fastabiq Khoiru Ummah Pati diterima

4) Produk, promosi dan pelayanan secara bersama-sama berpengaruh signifikan terhadap keputusan anggota non muslim. Hal ini dilihat dari nilai F hitung sebesar 17.997 dengan signifikansi 0.000 yang jauh di bawah 0.05 , sehingga hipotesis yang menyatakan bahwa pelayanan, produk dan promosi secara bersama-sama berpengaruh signifikan terhadap keputusan anggota non muslim pada KSPPS Fastabiq Khoiru Ummah Pati diterima, dengan besarnya pengaruh sebesar 51\%. 


\section{DAFTAR PUSTAKA}

Anwar (2003), Realibilitas dan Validitas, Pustaka Pelajar, Yogyakarta.

Arbi Syarif (2002), Mengenal Bank dan Lembaga Keuangan Non Bank, 2002, Djambatan, Jakarta

Evi Yupitri dan Raina Linda S (2012), Analisis Faktor-faktor Yang Mempengaruhi Non Muslim Menjadi Nasabah Bank Syariah Mandiri di Medan, Jurnal Ekonomi dan Keuangan, Vol.1. No.1 Desember.

Farida Yulianti (2012), Apresiasi Nasabah Terhadap Produk Perbankan Syariah Di Kota Banjarmasin, Jurnal Spread - April, Volume 2 No 1

Hermawan K. \& Muhammad S.S (2006), Syari'ah Marketing, Bandung: Mizan Pustaka. Indriyo Gitosudarmo (1997), M. Com., Manajemen Pemasaran, Yogyakarta: BPFE Yogyakarta.

Moenir (2002), Manajemen Pelayanan Umum Di Indonesia, Bumi Aksara, Jakarta Martono, (2002), Bank dan Lembaga Keuangan Lain, Yogyakarta: Ekonosia.

Muhammad Muflih (1989), Lembaga Keuangan Syariah, Raja Grafindo Persada, Jakarta. Muhammad, (2008), "Metodologi Penelitian Ekonomi Islam Pendekatan Kuantitatif". Jakarta: Rajawali Pers.

Philip kotler dan A.B.Susanto (2001), Manajemen Pemasaran Di Indonesia, Salemba Empat, Jakarta.

Rambat Lupiyoadi \& A. Hamdani (2006), Manajamen Pemasaran Jasa, Edisi 2, Jakarta: Salemba Empat.

Ridwan Muhammad, Manajemen Baitul Maal Wa Tamwil; Yogyakarta: Press, 2004.

Sedyana, (1995) Perilaku Konsumen, Bandung: Presko.

Saifuddin Azwar, (2004), Metode Penelitian, Pustaka Pelajar, Yogyakarta.

http://bmtfastabiq.com/profil.php//diakses tanggal 5 November 2018 